\title{
WHAT CAN BE DONE WITH TREATMENT OF ATTENTION DEFICITS IN PERSONS WITH VISUAL IMPAIRMENTS?
}

\author{
Dragana Maćešić-Petrovića,* \\ Vesna Žigića \\ Jasmina Kovačevića \\ Zora Jačova ${ }^{\text {b }}$
}

Original scientific paper

University of Belgrade, Faculty of Special Education and Rehabilitation, Serbia ${ }^{a}$

University "St. Cyril and Methodius", Faculty of Philosophy, Department of Special Education and Rehabilitation, Republic of Macedonia

Received: 09.02.2016

UDC:376.1-056.262:159.952.6

Accepted: 28.02.2016

$159.952-056.262$

\begin{abstract}
The paper focuses the quallity of attention processes in children with visual impairments on special educational, rehabilitational and medical treatment. The subjects of research were 52 examinees from the School for children with visual impairments in Belgrade. In the sample were present $25 \%$ of the legally blind children and $75.0 \%$ of blind children. The quallity of attention wass estimated by Cancellation test (adapted version which comprise items with geometrical objects). The results of research point out the suxssess of the tested sample on the implemented instrument. Complex, pervasive chronically disturbances such as attention disability with or without hyperactivity at the population with visual impairments need complex oriented team approach in applied treatment such as multidisciplinary team work with special education treatment and medication therapy (psyhostimulanses $i$ atomoxetin) same as multimodal oriented treatment approach.
\end{abstract}

Key words: special education, drug therapy, attention deficits, visually impaired persons

\section{INTRODUCTION}

Poor vision in children means impaired visual performance as a result of impaired visual acuity and contrast sensitivity, visual field defects, and other related dysfunctions. Visual performance is severely impaired in a child with poor vision and cannot be corrected with medical, surgical, or accessory tools such as loupes (Calik et al, 2012).
Attention signifies selective perception of a limited number of stimuli or elements of information in the field of perception. The information selection depends on the current motivation and earlier experience, so that the same perception field does not always have the same motivation value, nor are the data it contains always selected in the same way.

\footnotetext{
$\overline{{ }^{1} \text { Correspodence to: }}$

Dragana Maćešić-Petrović, University of Belgrade, Faculty of Special Education and Rehabilitation

Visokog Stevana 2, 11000 Belgrade, Serbia

E-mail: macesicd@yahoo.com
}

*FUNDING: The study was realized within the research project "Creating a protocol to assess educational potential of children with disabilities, as a criterion for the development of individual educational programs", No. 179025, Ministry of Science and Technology, Belgrade, 2011-2016, project leader - Professor Jasmina Kovacevic, Ph.D. 
Attention is sometimes understood to be a factor of psychological focussing, being followed by characteristic body and motility phenomena occurring at the same time or accompanying the occurrence of focussing. The significance of voluntary attention processes are point up in studies of academic problems and teaching difficulties same as difficulties in rehabilitation activity. From this point of view they are defined in the following manner: "discrepancy between normal intellect and low productivity in the learning activity can be explained, to a certain extent, by increased fatigue, fluctuations in working ability, lowered level of attention and its instability, motor uneasiness and motor clumsiness, emotional-volitional deficiencies and behavioural disorders" (Luria, 1979; Dye et al, 2009). During teaching and rehabilitation, internal and external factors for maintaining attention as long as possible with visually-impaired children are applied: various emotional-intellectual preparations with a view to developing the motivation for adopting a particular subject-matter, the use of various method procedures in presenting teaching materials, an interesting way of highlighting particularly important parts of the contents for children to remember or recognise them, information grouping in such a way that it is possible to keep attention longer on details of special importance.

The development of cognition in a visually impaired person differs from development of cognition of the individuals with normal visual ability. That difference is affected by both individual factors (functional eye sight, prematurity, and additional handicaps) and environmental factors. Severely impaired vision is one of the principal factors that delay the neural development in early stages. It was reported that this delay affected several important areas of neural development, such as cognitive skills, linguistic skills, and social relationships. Additional problems such as developmental stagnation, regression, and autistic disorders are also reported in many visually handicapped children (Calik et al, 2012).

\section{The aim of the research}

Becouse of their significance in rehabilitation and education processes, in this research we try to identify the specifities of attentional disorders and possible attentional differences between two category of visual impaired children - low vision and blind children.

\section{METHOD}

\section{Participants}

The research was conducted on 52 participants from the "Veljko Ramadanović" School for children with visual impairments in Belgrade. The gender distribution of the tested sample were 24 girls and 28 boys. The participants were without any neurological, psychiatrical or other associated disabilities. In the sample were present all academic degrees ( from first to eight grade) on the standard rehabilitational treatment. The sample was formed of $25 \%$ of legally blind partcipants and $75.0 \%$ of blind partcipants.

\section{Instrument and Procedure}

We assess the voluntary attention processes by the Cancallation Test of geometric objects. It was modify for the purpose of this scientific exploration (Bertella et al., 2005). It was given to each subject the set of geometrical objects to explore them by their tactile, kinaesthetic and visuall abilitieties. We proposed the geometrical tactile image which is well known by subjects, at the left side of the given test and require from the participants to recognize them between more other offered geometrical symbols, at the right side of the given test items. The items were distributed into five lines and consist of five different geometrical figures. The participants has to differentiated, identified and named the certain target objects. The score was formed by the number of correct responses and by the time neded for completing the test, expressed in seconds.

Statistical procedures was consist of different methods of parametric and non-parametric statistical methods, such as frequencies, percentages, arithmetic mean, standard deviation, $\chi^{2}$ test, and $\mathrm{C}$ coefficient of corellation contingency.

\section{RESULTS}

The results on implemented test will be present according to the standard methodology procedure, vieweed as successful achievement (achievement up to 25 points), and unsuccessful achievement (achievement from 0 to 20 correct answers on the test) with minimal scores of 0 and maximum of 25 correct answers on the implemented test. 


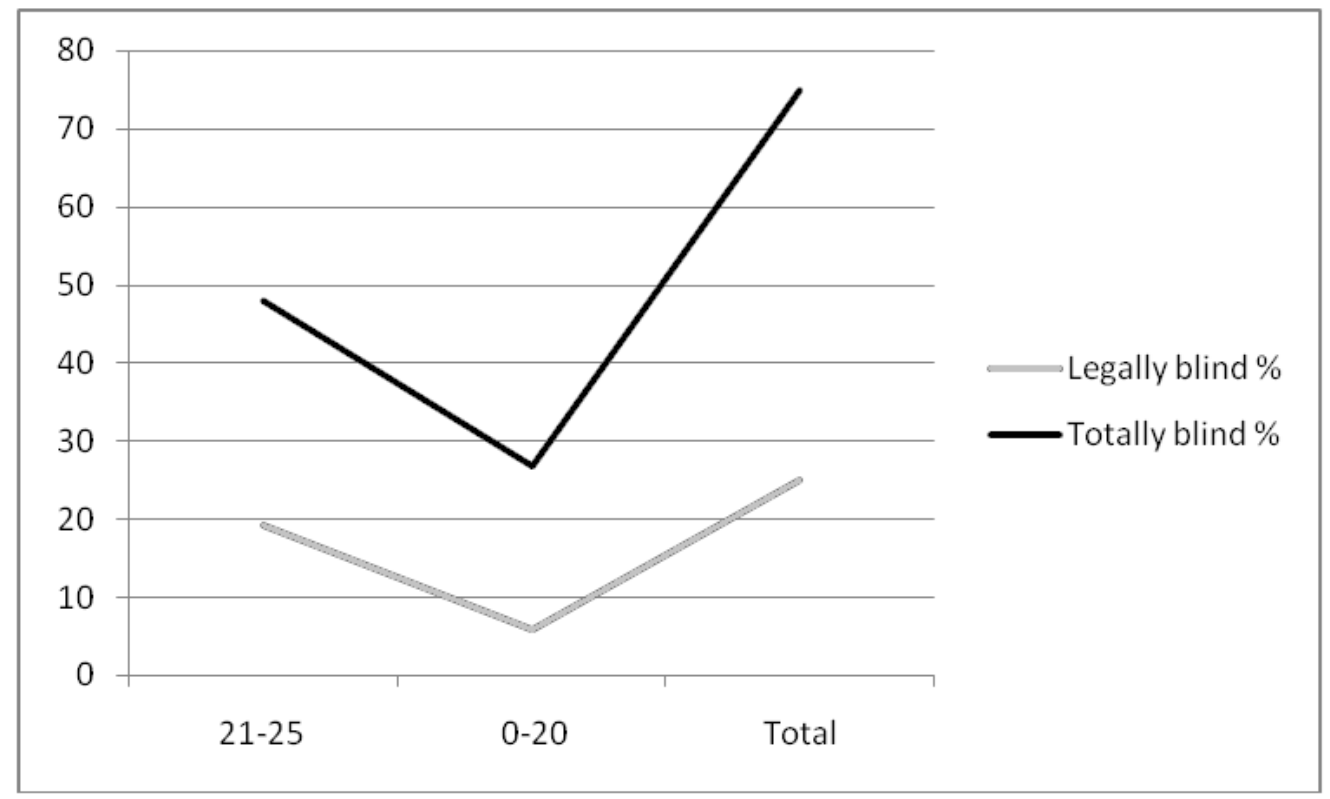

Figure 1-Results of the number of successful completed items

The successful achievement, which means achievement up to 25 points, obtained $48.1 \%$ of blind children and $19.2 \%$ legally blind participants. Unsuccessful achievement at the implemented test was obtained by $26.9 \%$ of totally blind participants and $5.8 \%$ of the legally blind children.

The achievement of the sample was also viewed throw the time (seconds) needed for completing the items.
The aritmethical average of the time needed for the completing the test was 162.29 seconds, with minimumof 30 seconds, and the maximum of 611 seconds. The most successfully subjects were blind, which can be the basic aim of our future investigations in this area and key finding in this research project. This research question is allso the object of our special interest in the area of statistical analysis (presented in Table 1).

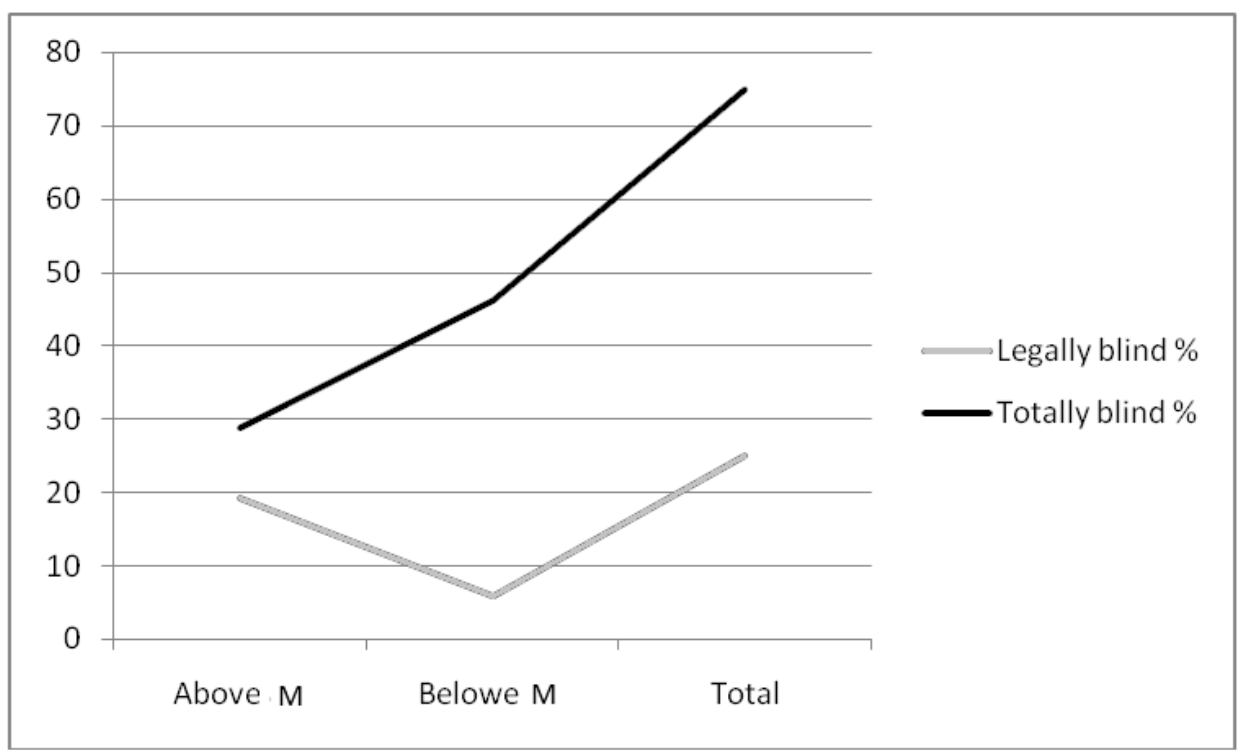

Graph 2 - Results of the time needed for completing the items

Results of the time needed for completing the items, indicates that $46.2 \%$ of totally blind children are unsuccessful at this part of test. At the category of suc- cessful results there are present $28.8 \%$ of totally blind and $19.2 \%$ of legally blind children. 
Table 1-The differences between tested variables in the groups of the sample

Number of successfully completed items

\begin{tabular}{llll}
\hline$\chi^{2}=7.5005$ & $\mathrm{dF}=1$ & $\mathrm{p}<0.01$ & $\Phi=0.3091$
\end{tabular}

Time of complete

\begin{tabular}{llll}
\hline$\chi^{2}=15.8369$ & $\mathrm{dF}=1$ & $\mathrm{p}<0.0001$ & $\Phi=0.4270$
\end{tabular}

The differences between the legally blind and totally blind participants in the time of completing the test and between the numbers of successfully completed items of the test are high statistically significant $(\mathrm{p}<$ $0.01-0.0001)$.

\section{DISCUSSION}

The results point up the conclusion about the significance of the applied treatment procedures implemented in this investigated sample. Complex, pervasive chronically disturbances such as attention disability with or without hyperactivity at the population with visual impairments need complex oriented team approach in applied treatment such as multidisciplinary and multimodal oriented approach which focuses the role of special educator and multidisciplinary team - child psychiatrist approach with social work and medication therapy (psyhostimulanses $\mathrm{i}$ atomoxetin) (Maćešić-Petrović et al, 2010).

Abilities of tactile and kinaesthetic perception and spatial recognition of different spacial objects and figures, which are included in the test items, demands adequate development of abilities of identification, which mostly is responsible for the results on this group of the test items. As well, it requires a harmonious growth of the orientation in the space at the level of micro-space such as the level of macro space, accountable for manipulative, graphical and motorical spatial activities. These are undeveloped capabilities in the population with visual impairments.

It is also important to note that child must have charmonical development of abilities to perceive and interpret the sensory contents relevant for symbolic meaning at the representational level of mental space and the ability to convert perceived tactile and kinaesthetic spatial elements of objects on the representational level of mental space. At the children with visual impairments this developmental area can be underdeveloped and determines the obtained research results (MaćešićPetrović, Vučinić et al 2005). This point out that spatial or temporal and object-based attention activities are organized by different neural bases which can be developed at various levels and reorganize by different strategies of treatment. (Dye \& Bavelier, 2010).

These results serves the conclude about the individual differencies of the tested subjects, observed in their attainmenton this items, which are determined by the specific development viewed throw the development of the tactile, kinaesthetic and manipulative abilities and their opportunities of conversion a spatial figure with a concrete meaning into symbolic meaning, or a geometrical symbol which requires to be identified andnamed as same as distinctinct it from other, alike spatially complet of figures. These are capabilities which are better functioning at the blind subjects toward to results of this exploration study and our other published projects results (Eškirović, 1996; Eškirović \& Vučinić, 1998; Maksimović, 2001; Maćešić-Petrović \& Vučinić, 2005). This is understanble because the blind children from early developmental stages must use their tactile-kynestetic and motor abilities to explore the space and world which surround them and to form the first concepts and conceptual categories of many objects observed by tactile, kinestetic and motor abilities which are the base of the perception and cognition. Blind children are better in this type of perception and recognition, same as tactile and motor attention, than children who are partially sighted (i.e.legaly blind).

Recent similar studies from our environment point out present deficits in area of visually-cognitive functioning and visually-motor abilities, same as in area of tactile and motor attention which can cause lower school achievement (Vučinić et al., 2012).

Complex, pervasive chronically disturbances such as attention disability with or without hyperactivity at the population with visual impairments need complex oriented team approach in applied treatment such as multidisciplinary and multimodal oriented approach which focuses the role of special educator and possible role of child psychiatrist with medication therapy (psyhostimulanses $\mathrm{i}$ atomoxetin) in the multimodal oriented treatment of attention disorders. 


\section{CONCLUSION}

The successful achievement, in the mean of number of correct answers, is present as achievement up to 25 points and obtained in $48.1 \%$ of blind children and $19.2 \%$ legally blind participants. At the category of time for completing the task, successful results are present in $28.8 \%$ of totally blind and $19.2 \%$ of legally blind children. Those are the key findings of our study. This means that blind children are better in tactile and manipulative recognizing the geometrical patterns but they need much longer time than legally blind children. Lower achievement in visually-motor integration in children with mild visual impairments are also point out in other similar studies in this research areas (Dye \& Bavalier, 2009; Eškirović, 1996; Eškirović \& Vučinić, 1998; Vučinić et al., 2012).

The findings of this research have highlighted the need to introduce and develop various intervention strategies for children with visual, cognitive and behavioral disorders. The final remarks include the state about the necessity of implementation the complete multimodal approach, which means different procedures and include:cooperation of different professions (psychiatrist, special educator, teacher and parents), multimodal treatment which means combination of rehabilitational methods, additional procedures (educational and psychological interventions same as social work, various educational strategies, such as reeducation of psychomotor activity etc.), medication therapy if it is required, individual educational programs (IEP) and individual treatment programs (ITP). The definition and description of the rehabilitation strategies must be directed towards characteristics of the development of the each child and to their capabilities. We also proposed the development and implementation of the new technics of rehabilitation in area of special education and we'll discuss it later.

As we have proposed the new methods, we can offer the methodological concept from our country, known from French speaking countries as Reeducation Treatment of Psychomotor Activity-RTPA. This theoretical, practical and conceptual frame includes the utilization of verbal and motor exercises, cooperation with child psychiatrist and practical activity given by a special educator as therapists. These activities have to improve the next performances:reduce motor or emotional impulsivity of the child, reduce distractibility of child's attention, improve cognitive strategies of the child, improve learning strategies of the child and mprove educational and self-educational strategies of the child, teachers and parents (MaćešićPetrović et al, 2010).

\section{REFERENCES}

Dye, M. W.G. \& Bavelier, D. (2010). Differential development of visual attention skills in school-age children. $\mathrm{Vi}$ sion Research, 50, 452-459.

Bertella, L. Girelli, G. Grugni, S. Marchi, E. \& Semenza, C. (2005). Mathematical skills in Prader-Willi Syndrome. Journal of Intellectual Disability Research, 49, 159-169.

Calik, B., Kitiş, A., Cavlak, U. \& Ğuzhanoğlu, A. (2012). The impact of attention training on children with low vision: a randomized trial. Turk J Med Sci; 42 (1). 1186-1193.

Eškirović, B. \& Vučinić, V. (1998). Pažnja slabovidih učenika. Beogradska defektološka škola, 2, 31-39.

Eškirović, B. (1996). Hiperkinetičko ponašanje i uspeh u školi slabovide dece osnovnoškolskog uzrasta. Beograd. Defektološki fakultet.

Lurija, N.B. (1979). Korekciono-vaspitni rad sa slabovidim učenicima. Moskva. Prosvešćenije.

Macešic-Petrovic, D., Lazic, D., Japundza-Milisavljevic, M. \& Đuric-Zdravković, A. (2010). Behavioral Disorders and Drug Therapy. The Open Conference Proceedings Journal, 109-114.

Maćešić-Petrović, D., Vučinić,V., Jablan, B. \& Eškirović, B. (2005). Attention in visually impaired children. Vision 2005 - Proceedings of the International Congress held between 4 and 7 April, 1282, 635-639.

Maksimović, J. (2001). Specifične teškoće učenika sa vizuelnim smetnjama u redovnoj osnovnoj školi. Beograd. Defektološki fakultet.

Vučinić, V., Gligorović, M., Jablan, B. \& Eškirović, B. (2012). Razvojne sposobnosti dece sa lakšim smetnjama vida. Specijalna edukacija i rehabilitacija, 4 (11). 585-602. 